\title{
Micro Credit as a Poverty Alleviation Tool in Turkey: A Case Study Analysis of Turkish Grameen Micro Credit Project
}

\author{
Hemin Ashrafi \\ Adjunct Faculty, Sonargaon University, Dhaka, BANGLADESH \\ E-mail for correspondence: heminash@yahoo.com
}

https://doi.org/10.18034/abr.v7i1.9

\begin{abstract}
Turkish Grameen Micro-credit Project (TGMP) follows Grameen Generalized System (GGS) which is designed to create new possibilities for a Grameen Bank Bangladesh(GBB) replication program by offering a simple and beneficial micro credit for improving poverty status of women in Turkey. Although GBB is known worldwide for its success in providing tiny credit without collateral to the poor women specially, still there have some controversy and questions about the methods and applications of the replication programs implemented in different parts of the world. The main objective of this study is to find the success of TGMP by evaluating some important factors related to the success of GBB replication program. By evaluating the program success of TGMP in eradicating extreme poverty, and improving the status of members' socio-economic life, this study concludes that it is quite successful till recent year as the GBB replication program especially in yearly performance, financial viability status, and loan performances of the members. Although TGMP has been proved successful in Turkey since 2003, it is recommended that necessary steps should be taken for its long-run success as a replication program of GBB with special concerns about financial sustainability, increase of growth oriented activities instead of home based loan activities and lending rate enhancement.
\end{abstract}

JEL classification: G21, O16, L31

Key words: Replication program; TGMP; GBB

\section{INTRODUCTION}

Inspired by the continuing success in poverty alleviation especially for women, the micro-credit model pioneered by Grameen Bank Bangladesh (GBB) has been replicated by thousands of micro-credit programs across the world. In Turkey, its replication program has started from 2003 through founding of Turkish Grameen Micro-credit Project (TGMP). Although TGMP is similar to GBB in its financial principles and organization of loan systems but still their performance, growth and impact may vary due to their different socio-economic conditions, members' lives and time period of association with this credit program which can affect its success rate as a Grameen Bank replicator (Grameen Trust 2010, Özer 2004).

Purpose of the Study

The main aim and purpose of this study is to evaluate the operational mechanism of TGMP by identifying the criteria and key factors which affect their smooth sustainable success as a replication program. Moreover, this paper seeks to find the scope of future thinking and necessary modifications for long-run sustainability of TGMP as a replication program of GBB.

\section{Data and Methodology}

Secondary data sources have been used for the analysis and description of this study which are taken from TGMP's different branches, official data series, yearly financial statements and the recent five year's annual and audit reports. In order to identify their program success this paper attempts to analyze their last five year's growth of performance and loan activities by computing operational self-sufficiency, loan disbursement, outstanding loans, repayment behavior and saving mobilization of the members. 


\section{FACTORS FOR THE SUCCESS OF TGMP Replication Program}

The success of a replication program can be evaluated by some factors which play very important role in a program operation. The success of TGMP also can be analyzed similarly by evaluating their performances depending on these factors. This can be stated as the following way:

\section{Saving Mobilization}

Following the Grameen model, TGMP members are encouraged to deposit a voluntary minimum amount of 1TL per week in their weekly meeting in order to present an example for other poor people on how to save their money and use it during their unforeseen essential expenses such as health care, children education or heating materials for the winter season. The year-wise saving status of TGMP members can be seen from the following table 1 :

Table 1: Year wise saving status of TGMP members

\begin{tabular}{|c|c|c|c|c|}
\hline Saving status of TGMP members & $\mathbf{2 0 0 5}$ & $\mathbf{2 0 0 6}$ & $\mathbf{2 0 0 7}$ & $\mathbf{2 0 0 8}$ \\
\hline $\begin{array}{c}\text { Savings Balance } \\
\text { Total savings collection-Total savings withdraw (In Turkish } \\
\text { Lira, TRL) }\end{array}$ & $123.809,50$ & $193.777,00$ & $343.893,00$ & $716.351,54$ \\
\hline Total savings collection & 190714 & 440359 & 862877.00 & $1649.017,04$ \\
\hline Total savings withdraw & 66904.50 & 246502 & 518984.00 & $932.665,50$ \\
\hline \% of savings withdraw & $35 \%$ & $55 \%$ & $60 \%$ & $56 \%$ \\
\hline
\end{tabular}

Source: Taken and Compiled from TGMP Annual Reports.

The saving balance trend for the recent year can be shown as the following figure 1 :

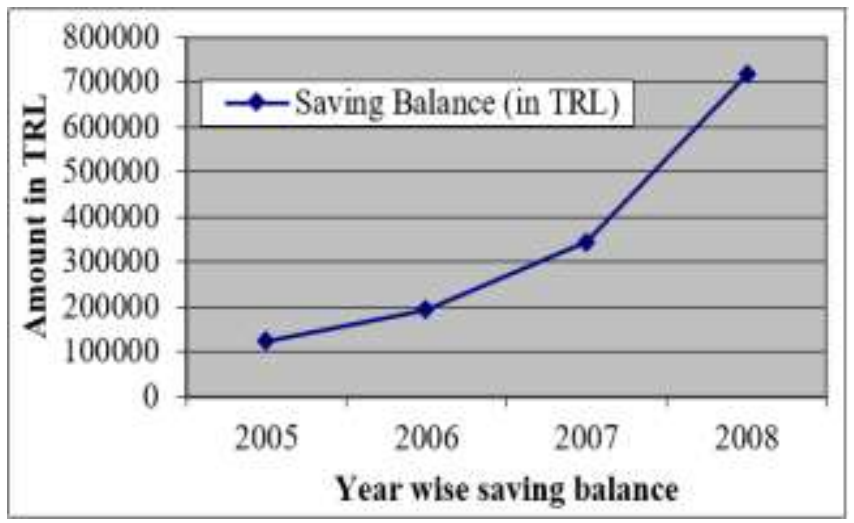

Figure 1: Yearly Saving Balance Status of TGMP Members
According to the recent annual reports of TGMP, the annual saving collection and balance maintains increasing trend from the year 2005-2008. Also from the recent records of TGMP the percentage of savings withdraw decreased by $4 \%$ in 2008 compared to 2007 . The weekly installment rate of the successfull borrowers also maintaing increasing trend for the recent year.

\section{Financial Viability Status of TGMP}

In case of financial viability, TGMP earned success in most of its operational parts. Since its establishment TGMP made sucess in loan disbursement and repayment sector. According to the annual report of 2008, TGMP has distributed $\$ 13.340 .000$ to its 16.556 members. The repayment rate is $100 \%$ which is one of the most important condiitons for an organization to be sustainable and viable. Also TGMP earned 100\% operational self-sufficiency since 2006.

Table 2: Year wise financial viability status of TGMP

\begin{tabular}{|c|c|c|c|c|c|c|c|}
\hline Performance status of TGMP & $\mathbf{2 0 0 3}$ & $\mathbf{2 0 0 4}$ & $\mathbf{2 0 0 5}$ & $\mathbf{2 0 0 6}$ & $\mathbf{2 0 0 7}$ & $\mathbf{2 0 0 8}$ & $\mathbf{2 0 0 9}$ \\
\hline $\begin{array}{c}\text { Total amount disbursed } \\
\text { (In dollar) }\end{array}$ & $\begin{array}{c}9473333 \\
(1 \mathrm{USD}=1.50 \mathrm{TRL})\end{array}$ & 270280 & 11064854 & 3702916 & 7664268 & 13339037 & $\begin{array}{c}2745025233 \\
(1 \mathrm{USD}=1.50 \mathrm{TRL})\end{array}$ \\
\hline Total amount outstanding & - & 161,757 & 440,915 & 1.107 .697 & 2.189 .723 & 4.228 .075 & - \\
\hline Operational self sufficiency & - & $40 \%$ & $78 \%$ & $100 \%$ & $100 \%$ & $100 \%$ & - \\
\hline Rate of repayment & - & $100 \%$ & $100 \%$ & $100 \%$ & $100 \%$ & $100 \%$ & - \\
\hline
\end{tabular}

Source: TGMP Annual Reports 2005-2009. http:/ /www.tgmp.net/eng/index.html

It can be seen from the observed report (mentioned in table 2) that TGMP is maintaining sustainability in loan disbursement, operational self sufficiency and rate of repayment sector which is very important factors for the financial institutes to be sustainable.

\section{Improvements in Members' Socio- Economic Condition}

A program's overall success also depends on the wellbeing of its members' socio economic condition. To find the positive impact and success of TGMP, data of 48 successful members have been collected from different branches mainly from Baglar, Sur, Bismil, Mardin, Silvan, etc. of Diyarbakir area which is the oldest area of using TGMP loans. On the basis of 
analyzing the members' performances in different areas like entrepreneurship, decision making, status inside family, better quality of life, improvement in health facility and conditions and improvement in children conditions, it can be observed that TGMP can be able to maintain a success trend till recent year for uplifting women's socio economic condition. TGMP program success and effects on its borrowers' life have been discussed below on the basis of the data set observations:

\section{Entrepreneurship Status of TGMP Members}

TGMP has entrepreneurship loan program for the most capable, efficient, hardworking members who would like to carry their activities on a large scale and want to use their capital in a small business and entrepreneurship purpose with the support of TGMP loans. The year-wise micro-entrepreneurship loan status of TGMP members can be observed from the figure 2 below:

Figure 2: Year-wise Micro-enterprise Loan Delivery Status

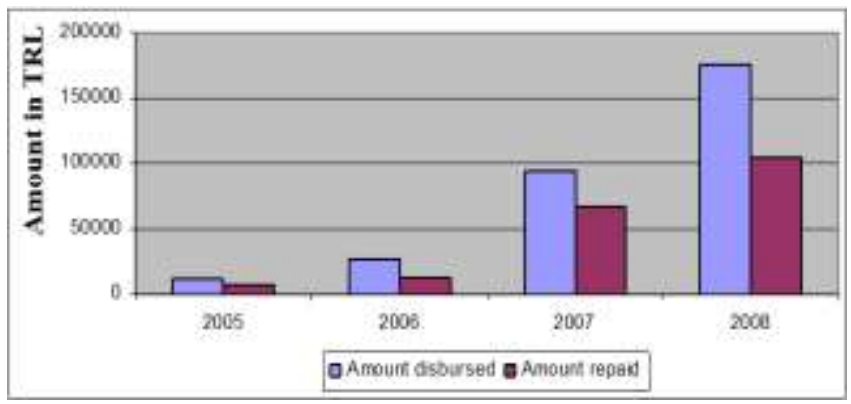

As of December 2008, 3700 members received total of 176354 TRL entrepreneur loans which has increased from 48 members by giving total amount of 9465700 TRL in the year 2007. The amount of disbursement and repayment has increased from the year 20052008. But the repayment rate is slower compare to disbursement rate especially for the year 2007-2008.

\section{Decision making and Better Quality of Life Status of TGMP Members}

Through achieving economic empowerment $74 \%$ of the observed data set members are the major decision maker along with their husband inside their family. Economic empowemrent can raise the status of a borrower inside their family. According to their statement, after joining TGMP, $79 \%$ of the members uplifted their socioeconomic status. Moreover, $13 \%$ of them are successful to raise their status within their family and $8 \%$ of the successfull members feel that they achieved empowerment from all perspects. Overall the members and her family owned a house with better facilities and quality of heating, bathroom, kitchen, sleeping and drawing room by the benefit of TGMP Loans.

Improvement in health facility and children condition of TGMP Members

According to the analysis of this data set it can be said that $96 \%$ of the members are successful to raise better health condition including health insurance and other facilities by joining TGMP loan program. $4 \%$ of them feel that their conditions remain same. According to the study, 57\% of TGMP members are successful to improve the education and schooling condition of their children. Also 39\% are capable to improve their children's health condition by joining TGMP. On the basis of these observations it can be said that TGMP can be able to maintain a success trend till recent year for uplifting women's socio-economic conditions which is an important factors for a program success.

\section{The Recent Performance of TGMP}

According to the recent report of TGMP, it is successful to expand its program to 65 villages all around Turkey. As of 2009 report, it has 55 branches where it was 32 in the year 2008. Similarly it increased its groups and centers compare to the previous year. According to the annual report of 2009, TGMP has now 2032 centers and 6273 groups. The number is also increased by 778 and 2748 respectively.

\section{Year Wise Performance Growth of TGMP}

TGMP is succeeded to increase its year wise loanee gradually. The number of $5^{\text {th }}$ year loanee is increased from 23 to 248 in 2008 compare to 2007 . It can be seen from the figure 3 below:

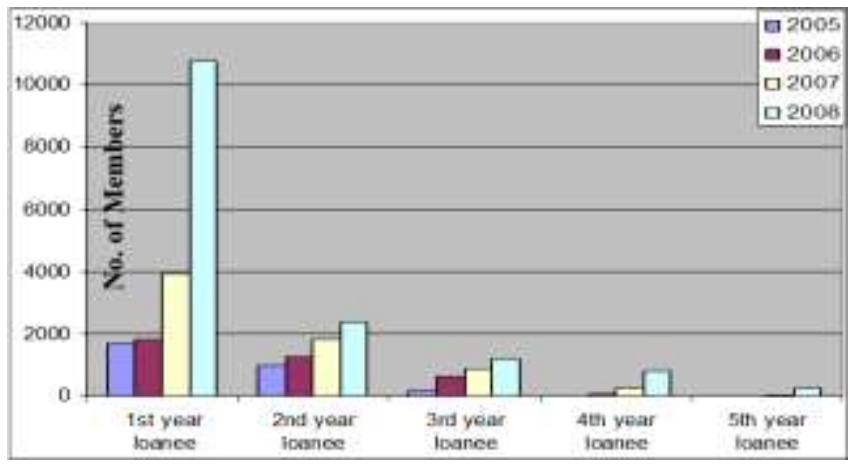

Figure 3: Year-wise TGMP's Basic Loanee Status.

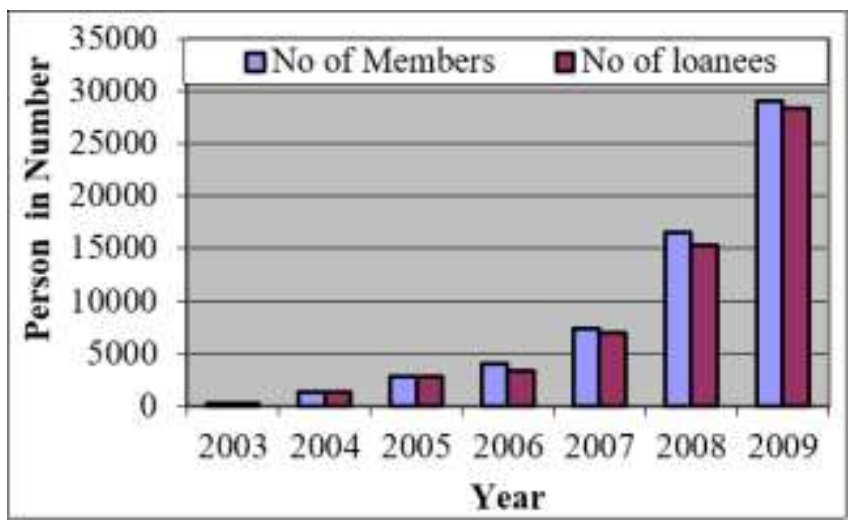

Figure 4: Year wise number of members and loanees Source: TGMP Annual Reports 2003-2009.

http://www.tgmp.net/eng/index.html

The maximum number of members are $1^{\text {st }}$ year loanee. TGMP is maintaining an increasing trend for all year 
loanee. Also TGMP has achieved success to increase the number of members and loanees at the same time. The percentage of drop out members has also decreased in $2008(16 \%)$ compare to 2007 (18.73\%).

\section{Types of Loans}

TGMP follows Grameen Generalized System (GGS) which is designed to create new possibilities for microcredit programs. Normally TGMP has five different types of loans for the better life of the poor women and to meet their various needs. TGMP members generally start with a single loan which is known as the Basic Loan. TGMP also provides loans of Flexible or contract loan, Micro enterprise loan, Micro Vegitunnel and Animal husbandry loan. Moreover, TGMP gives loan opportunity for the struggling members also. By using flexible loans the member gets some flexibility towards the payment of her loan, get rid of their loaning difficulties and at the same time it motivates them to work harder in order to make the payments on time in the future. The micro veggie tunnel loan helps the member to build small Vegitunnel or micro greenhouse system that can be used for growing fruits and vegetables in a more easy and developed way. The animal husbandry loan is an additional loan which is given to the existing members who have previous experience about cattle cultivation and animal husbandry. TGMP is maintaining success trend till recent year in these types of loans.

\section{Sector Wise Loan Activities}

According to the annual report of TGMP 2008, among all the sectors, the membership growth and percentage of loan is highest for the production and processing sector. Then the second one is the shop sector where the membership and percentage of loans both has increased more than the other sectors (TGMP Annual Reports 20062009). The sector-wise loan activities of TGMP members' in form of amounts in number and percentage can be expressed by the following table 3 :

Table 3: Sector wise loans and membership growth of TGMP

\begin{tabular}{|c|c|c|c|c|c|c|c|c|}
\hline \multirow[t]{2}{*}{ Name of the sectors \& purposes } & \multicolumn{2}{|c|}{2005} & \multicolumn{2}{|c|}{2006} & \multicolumn{2}{|c|}{2007} & \multicolumn{2}{|c|}{2008} \\
\hline & $\begin{array}{c}\text { Member } \\
\text { In number }\end{array}$ & In $\%$ & $\begin{array}{c}\text { Member } \\
\text { In number }\end{array}$ & In $\%$ & $\begin{array}{c}\text { Member } \\
\text { In number }\end{array}$ & In $\%$ & $\begin{array}{c}\text { Member } \\
\text { In number }\end{array}$ & In $\%$ \\
\hline Processing \& Production & 894 & $18 \%$ & 1971 & $20 \%$ & 2888 & $21 \%$ & 3711 & $21 \%$ \\
\hline Agriculture & 160 & $3 \%$ & 410 & $4 \%$ & 687 & $5 \%$ & 993 & $6 \%$ \\
\hline Domestic animals & 793 & $15 \%$ & 1335 & $14 \%$ & 2220 & $16 \%$ & 3180 & $17 \%$ \\
\hline Services & 452 & $9 \%$ & 976 & $10 \%$ & 1101 & $8 \%$ & 1490 & $8 \%$ \\
\hline Business and trade & 864 & $17 \%$ & 1458 & $15 \%$ & 2475 & $18 \%$ & 3080 & $17 \%$ \\
\hline Peddlery & 452 & $9 \%$ & 858 & $9 \%$ & 1788 & $13 \%$ & 1987 & $11 \%$ \\
\hline Shop & 1449 & $29 \%$ & 2677 & $28 \%$ & 2615 & $19 \%$ & 3580 & $20 \%$ \\
\hline Total & 5064 & $100 \%$ & 9685 & $100 \%$ & 13754 & $100 \%$ & 18021 & $100 \%$ \\
\hline
\end{tabular}

Source: Compiled and taken from TGMP Annual reports 2005-2008.

\section{SUCCESS IN ACHIEVING ECONOMIC EMPOWERMENT OF THE MEMBERS}

According to the study of (Khandker and Chowdhury 1996), credit program associated with time period is very important to achieve economic empowerment and economic graduation. To evaluate success of a credit program like TGMP it is very important to analyze its loan performance associated with membership length.
Loan Performance Associated with Membership Length

According to the collected data set of 48 successful TGMP members in this study, the loan using status and associated time period with TGMP of the members can be stated as the following table 4 from where it can be observed that for all of these 48 members, the average time period of their membership is 27 months and average total amount of loan is 2670 TRL.

Table 4: Loan taking performance of the data set

\begin{tabular}{|c|c|c|c|}
\hline $\begin{array}{c}\text { No. of loans Taken from } \\
\text { TGMP }\end{array}$ & $\begin{array}{c}\text { No. of members } \\
\text { (in \%) }\end{array}$ & $\begin{array}{c}\text { Membership length in months before } \\
\text { cease to take loans (in average) }\end{array}$ & $\begin{array}{c}\text { Total amount of loans taken } \\
\text { from TGMP (in average) }\end{array}$ \\
\hline & $5(11 \%)$ & 7.4 & \\
\hline 1 & $7(15 \%)$ & 8.4 & 560 \\
\hline 2 & $2(4 \%)$ & 29 & 4145 \\
\hline 3 & $31(64 \%)$ & 32.8 & 2812 \\
\hline 4 & $1(2 \%)$ & 40 & 5400 \\
\hline 5 & $2(4 \%)$ & 37.5 & 4876 \\
\hline
\end{tabular}

Source: Author's calculation on the basis of the collected data set 
According to the collected data set, $64 \%$ of the successful members have taken 4 times loan within average time duration of 33 months of their membership period to overcome their poverty condition and economic empowerment. $11 \%$ (with an average membership period of 7.4 months) and $15 \%$ (an average membership period of 8.4 months) of them have taken 1 and 2 times loan respectively. The average total amount of loan is 2812 Turkish lira for the members who have taken 4 times loan. The average total amount of loans for the members who have taken 1, 2 and 3 times of loan ( $4 \%$ of the successful members with an average membership time period of 29 months) are 560, 1145 and 4700 Turkish lira respectively. Only a few members have taken 5 $(2 \%)$ and $6(4 \%)$ times loan. Although for both categories of these members' average total amount of loans are the maximum. In detail, the status of loan using times in form of numbers can be seen from the following figure 5 :

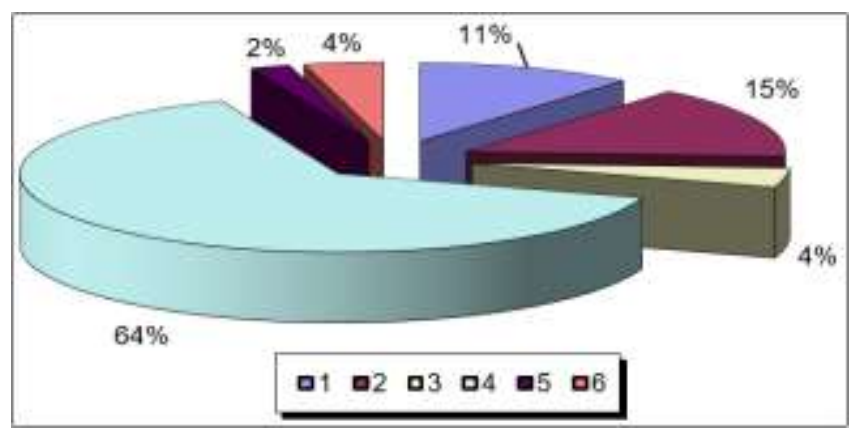

Figure 5: Number of loans taken by the members Source: From the observed data set

There is a tendency of taking loans in a regular and frequent basis to improve their lives and poverty conditions. According to the data set, the new members compare to the old members are more active in loan performance. There is a tendency in new members to take loans more quickly than the old members. From the above figure it can be observed that $64 \%$ members of the observed data set taken 4 times loan. Here the numbers $(1,2$, 3 ...) express how many times the members have taken loans from TGMP. The relation of the members' number of taking loans with their membership length can be seen from the figure shown below. The average membership length for each number of loans can be seen from the following figure 6 :

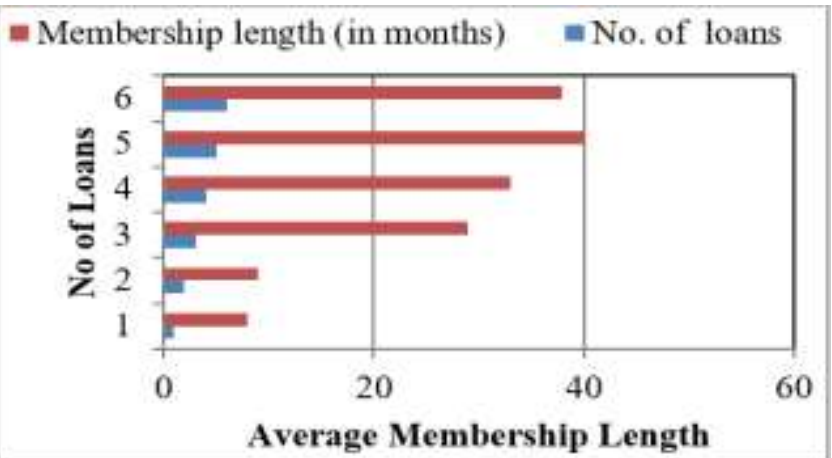

Figure 6: Relation between loan performance and membership length

Source: Compiled from the observed data set
From the above figure a positive loan performance can be observed with membership time period. The number of loan taken by the members' increases with their membership length.

\section{ConcLusion}

It can be concluded that the success of Grameen Bank project in Turkey mostly depends on how early poor people repay their loan and reach to economic empowerment status. TGMP is successful in almost all the area till the recent year. But as it is quite a new project still there should be further study, research and recommendations need to be sorted out for the long run success of TGMP as a replication program. Increase of growth oriented activities instead of home based loan works, lending rate or annual disbursement enhancement according to the ability of the borrowers are highly recommended to make this kind of replication program more beneficial. It can be further concluded that like TGMP, other Grameen Bank project ideology as a replication program implemented in different countries can be evaluated by estimating membership time period, their rate of repayment, dropout rate and thus eradicate the poverty of poor people.

\section{REFERENCES}

Grameen Trust. 2010. Last modified November, 2010. http://www.grameentrust.org/bot.html. [Accessed 25.03.2011]

Khandker, Shahidur R. and Osman H. Chowdhury. 1996. "Targeted Credit Programs and Rural Poverty in Bangladesh", World Bank Discussion Paper 336, Washington D.C.: World Bank.

Özer, Sinem. 2004. "Turkey's Experience With Micro credit: The New Governmental Strategy". Master diss., Boğaziçi University.

TGMP. 2005-2009. Turkish Grameen Micro-credit Project, Yearly Annual Reports, Last modified October 9, 2010. http://www.tgmp.net/eng/Financial.html. [Accessed 25.03.2011]

$$
--0-
$$


Online Archive: https://abc.us.org/ojs/index.php/abr/issue/archive 5. WorldCat Google scholar abcGATE \BASE 